\title{
PALAVRA CANTADA: A POTÊNCIA COMUNICATIVA, O ENCANTO ESTÉTICO E USO PEDAGÓGICO DO ACALANTO NA FORMAÇÃO DE LEITORES INFANTIS
}

\author{
PALAVRA CANTADA: THE COMMUNICATIVE POWER, THE AESTHETIC \\ CHARM AND THE PEDAGOGICAL USE OF ACALANTO IN THE \\ FORMATION OF CHILDREN READERS
}

Bruno Guedes Pinto ${ }^{1 *}$

Ilioni Augusta da Costa $^{2}$

${ }^{1}$ Instituto Federal do Espírito Santo. E-mail: guedespinto.bruno@gmail.com

${ }^{2}$ Instituto Federal do Espírito Santo. E-mail: ilionicosta@yahoo.com.br

*Autor para contato

Artigo submetido em 03/08/2019, aceito em 01/09/2019 e publicado em 20/12/2019

Resumo: O objetivo deste trabalho é investigar as características do subgênero textual acalanto dentro do espectro de produções artísticas destinadas ao público infantil quanto à sua eficácia comunicativa, ao seu encanto estético e ao seu uso pedagógico na formação de leitores e no processo de ensino e aprendizagem, desde os primeiros anos de alfabetização. Para tal, serão analisados os recursos sonoros e linguísticos operados na confecção das faixas do álbum "Canções de ninar", do projeto Palavra Cantada.

Palavras-chave: Palavra cantada; acalanto; formação do leitor; semiótica.

Abstract: This work seeks to investigate the characteristics of the textual subgenre acalanto within the spectrum of artistic productions destined to the children regarding its communicative efficacy, its aesthetic charm and its pedagogical use in the formation of teaching and learning process since the first years of literacy. This study analyzes the sound and linguistic resources used in the making of the tracks of the album "Canções de ninar", by the project Palavra Cantada.

Keywords: Sung word; acalanto; reader training; semiotics.

\section{INTRODUÇÃO}

A canção é um gênero textual multimodal que atravessa a história da humanidade resistindo às tantas mudanças na sensibilidade humana, nas instituições sociais e nos contextos políticos (RUFINO, 2012). Por mais que a funcionalidade do gênero tenha se adaptado às novas práticas sociais de leitura e escrita, a canção segue com seu poder encantatório e sua eficácia comunicativa, despertando, desde a mais tenra infância, as potencialidades comunicacionais, linguísticas, sonoras, dinamogênicas ${ }^{1}$, informativas e culturais

\footnotetext{
${ }^{1}$ Inda [sic] estará certo a gente chamar uma música de molenga, violenta, comoda [sic] porquê [sic] certas dinamogenias fisiológicas amolecem $\mathrm{o}$
} 
dos participantes de seus espaços de interação.

Investigar as características do subgênero textual acalanto dentro do espectro de produções artísticas destinadas ao público infantil quanto à sua eficácia comunicativa, ao seu encanto estético e ao seu uso pedagógico na formação de leitores e no processo de ensino e aprendizagem desde os primeiros anos de alfabetização é o ponto central deste trabalho.

Serão analisados os recursos sonoros e linguísticos operados na confecção das faixas do álbum "Canções de ninar" (PERES; TATIT; 1994), do projeto Palavra Cantada, para explorar a importância pedagógica de operar um gênero textual multimodal e dinamogênico como a canção. Mas o que é um gênero textual?

\section{OS GÊNEROS TEXTUAIS: UM BREVE PERCURSO}

Na sua gênese, a Teoria dos Gêneros Textuais foi influenciada pelo materialismo dialético e histórico, de Marx e Engels, recuperando para os estudos linguísticos o elo entre o texto, a situação enunciativa e o contexto discursivo, afinal os gêneros são definidos como "[...] tipos relativamente estáveis de enunciados que se constituem historicamente a partir das situações de interação verbal. Esta afirmação parte da ideia de que a língua é uma atividade social, histórica e cognitiva" (CALAZANS, 2011, p. 01).

O conceito de gêneros textuais põe em destaque a importância das interações psicossociais na formulação de modelos comunicativos, culturais e sociocognitivos, com estruturas textuais específicas, usados para atender a funções sociais determinadas por diretrizes culturais e contextuais de um evento comunicativo (BAKHTIN, 2003).

organismo, regularisam [sic] o movimento dele ou o impulsionam. Estas dinamogenias nos levam para estados psicológicos equiparáveis a outros que já tivemos na vida. Isto nos permite chamar um trecho musical de tristonho, gracioso, elegante, apaixonado etc. etc. Já com muito de metáfora e bastante de convenção (ANDRADE, 1972, p. 41).
O gênero textual é considerado, inclusive, como uma ação de fala dentro de um conjunto de diversas ações que compõem um evento social, ou seja, "[...] os gêneros textuais se apresentam como ações sócio-discursivas para agir sobre o mundo e dizer o mundo. Como ações sóciodiscursivas, os gêneros contribuem para organizar as atividades comunicativas do dia-a-dia" (CALAZANS, 2011, p. 02).

Fazer uma criança dormir, por exemplo, é um evento, demanda de seus integrantes várias ações para se atingir o objetivo proposto (dentre elas, cobrir a criança, acarinhá-la, apagar a luz do seu quarto, afofar-lhe o travesseiro etc.). $\mathrm{O}$ acalanto também é uma ação muito comum a esse tipo de evento, mas difere das demais, pois se constitui como um ato levado a cabo por um (ou mais de um) sistema(s) de representação (o linguístico, o sonoro, o gestual etc.) (FALBO, 2010).

Os gêneros textuais se caracterizam por virtualmente compor um modelo interativo de ordenamento cultural de (pelo menos) um sistema de representação que busca responder a uma demanda de determinado contexto sócio-históricointeracional: sem demanda, de que serve uma lista telefônica?

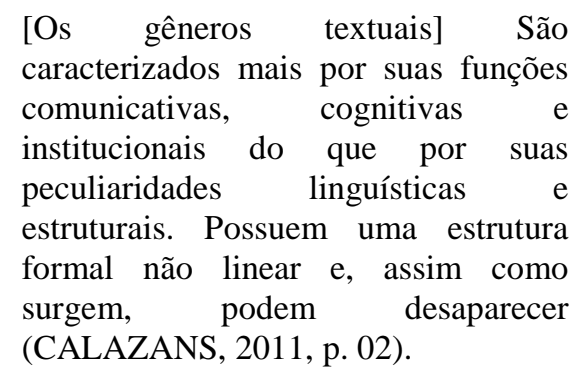

Apesar de os gêneros textuais serem esses esquemas cognitivos e interativos préestabelecidos culturalmente, ou nas palavras do próprio Bakhtin "[...] situações típicas da comunicação discursiva, a temas típicos, por conseguinte, a alguns contatos típicos dos significados das palavras com a realidade concreta em circunstâncias típicas" (BAKHTIN, 2003, p. 293), eles ainda guardam a possibilidade de inovação e 
criatividade, de maneira variável a depender do gênero textual.

Essa liberdade inventiva e não linear de todo gênero textual é mais presente num texto literário como o romance do que num formulário cadastral, por exemplo; ambos são gêneros textuais, mas o último é um texto mais rígido, mais objetivo quanto à sua função e obediente aos padrões culturais historicamente mais estáveis, mais lineares e menos dialógicos.

Como os gêneros textuais intervêm diretamente nas relações interpessoais e/ou institucionais, pode-se considerá-los uma ação retórica de um sujeito da enunciação dentro de um evento e que se constitui em diálogo com a organização social com a qual interage, interação pela qual se constroem mutuamente - $\mathrm{o}$ ato de fala como qualquer ato na vida se engendra enquanto é engendrado.

O fazer de uma ação enunciativa como o acalanto exerce sua função ao atingir um determinado objetivo, no caso, fazer uma criança dormir. $\mathrm{O}$ objetivo buscado pelo acalanto, por outro lado, está marcado na estrutura desse gênero textual: pragmaticamente, a situação enunciativa exige um canto intimista, à capella, uma melodia tematizante em tom médios, uma performance acalentadora e acolhedora, o que interage, cognitiva, dinamogênica $\mathrm{e}$ culturalmente, com as demandas da situação de enunciação, afinal "[...] todos os gêneros têm uma forma e uma função, bem como um estilo e um conteúdo, mas sua determinação se dá basicamente pela função e não pela forma" (MARCUSCHI, 2008, p. $150)$.

O acalanto, nesse exemplo, aparece como um gênero textual mais ou menos estável, mesmo que seja aberto a mudanças estruturais e de estilo, esse gênero ainda assim continuaria a ser um acalanto, contanto que a função de fazer dormir se mantenha (BAKHTIN, 2003). Caso o texto esvaeça a funcionalidade do gênero textual, provavelmente se atingirá uma produção de natureza diversa que, obviamente, acarretará numa transmutação para um gênero limítrofe (outro tipo de canção folclórica ou ainda um exemplar de canção popular).

Sempre que um evento social, com as suas especificidades culturais, exige a produção de uma forma específica de ação envolvendo signos (linguísticos ou não), o sujeito vai partir das convenções culturais previamente estabelecidas para dar corpo ao texto, definir as condições de dizer possíveis ao contexto enunciativo e inserir a sua produção e a si mesmo no continuum político-discursivo do recorte social e ideológico do qual faz parte:

A canção, assim como o poema, pertence ao campo literário. A canção estaria no que Maingueneau (2005) chama de discurso literário. Para o autor, falar em discurso literário é renunciar a um espaço consagrado, pois as condições de dizer [grifo nosso], ainda em referência ao autor, atravessam o dito, que investe suas próprias condições de enunciação (RUFINO, 2012, p. 11-12).

A canção é um gênero textual intersemiótico e isso é fundamental na sua diferenciação de outros gêneros, apesar das semelhanças que possui com o poema e a música instrumental. Possui indissociável relação entre palavra e som, entre texto verbal e não verbal, sendo, nesse sentido, preferencialmente analisável como uma produção multimodal (COSTA, 2003).

\subsection{O GÊNERO TEXTUAL CANÇÃO}

A canção é uma produção temporal breve que envolve a cooperação de, pelo menos, dois sistemas de representação, o linguístico e o musical, por isso nenhuma análise pode prescindir da relação entre ambos.

O canto é um elemento fundamental na constituição da canção enquanto um gênero textual, uma voz que cria um padrão sonoro mais ou menos estável para entoar a letra da canção. A canção pode ou não ser acompanhada por instrumentos, como é o caso das execuções à capella. O canto, portanto, não é a produção e sustentação de 
um som de altura definida, um canto não existe sem voz, parece redundante, mas a vocalidade do canto é fundamental para a canção e possui traços distintivos da oralidade e da fala, como se verá.

$\mathrm{O}$ arranjo e a escolha dos instrumentos que compõem o canto e a harmonia entre eles, o ritmo, os gêneros musicais e sua construção sócio-histórica: todos esses elementos são fundamentais à sua produção e, consequentemente, a uma análise da canção, mas, para se ter dimensão da importância do canto na canção, o semioticista Luiz Tatit (1986) se concentra nas heranças entoativas que constroem as melodias executadas pelo canto e que conferem eficácia comunicativa e encanto estético à canção quando compatibilizadas com a interface linguística da obra.

A canção contém em si o gene da transformação e da adaptação a novas organizações sociais, situações enunciativas, configurações estruturais, fatores pragmáticos, estilos, conteúdos, tecnologias etc. A história da canção entrelaça-se na história do homem. Pode-se constatar a capacidade de transição da funcionalidade da canção, sem que, com isso, haja uma transmutação de genericidade (MARCUSCHI, 2008).

Bakhtin identifica dois grupos distintos de gêneros textuais no vasto universo discursivo, que "[...] compreenderia o conjunto de formações discursivas de todos os tipos interagindo em uma dada conjuntura" (COSTA, 2003, p. 13).

O primeiro grupo é formado pelos gêneros primários, são enunciados em situações comunicativas rotineiras, geralmente esses gêneros atendem a necessidades e/ou desejos interativos imediatos, como o bilhete e o diálogo cotidiano. Bakhtin, por outro lado, assim define os gêneros secundários:

[...] surgem nas condições de um convívio cultural mais complexo e relativamente muito desenvolvido $\mathrm{e}$ organizado (predominantemente $\mathrm{O}$ escrito) - artístico, científico, sócio- político, etc. No processo de sua formação eles incorporam $\mathrm{e}$ reelaboram diversos gêneros primários (simples), que se formaram nas condições da comunicação discursiva imediata. Esses gêneros primários, que integram os complexos, aí se transformam e adquirem um caráter especial: perdem o vínculo imediato com a realidade concreta e os enunciados reais alheios: por exemplo, a réplica do diálogo cotidiano ou da carta no romance, ao manterem a sua forma e o significado cotidiano apenas no plano do conteúdo romanesco, integram a realidade concreta apenas através do conjunto do romance, ou seja, como acontecimento artísticoliterário e não da vida cotidiana (BAKTHIN, 2003, p. 263).

A canção também é capaz de reelaborar diversos gêneros primários, sem dúvida o diálogo cotidiano é o gênero primário que mais é apropriado e reformulado por ela: “[...] esta condição [ação simulada onde alguém diz alguma coisa de uma certa maneira a outro alguém], por si só, já traz à canção um estatuto popular, pois todos podem reconhecer situações cotidianas de conversa [grifo nosso]" (TATIT, 1986, p. 06).

Existem, no conjunto universo, três tipos de canção: a folclórica, a erudita e a popular. A canção popular possui maior liberdade na execução do que a música erudita, isso se deve ao fato de a canção popular não estar ligada à notação musical, à partitura. A canção popular geralmente possui uma autoria conhecida, o que a diferencia da canção folclórica, e é multifacetada em gêneros musicais. Suas obras movimentam um setor econômico lucrativo do ramo do entretenimento e sofrem com a influência do mercado mais do que a canção erudita.

Desde os tempos da invenção do rádio até os dias de hoje, muita coisa mudou para a história da canção, inclusive o interesse do mercado financeiro. A canção virou um produto comercial e como objeto de consumo é tratada, estratificada em nichos mercadológicos, como vem ocorrendo nas últimas décadas com o 
robustecimento da reserva de mercado da canção popular infantil, tantas vezes em detrimento do caráter artístico da obra para favorecimento de seu viés pedagógico, moralizante e informativo (COSTA; GONZALEZ, 2014).

Uma parcela expressiva da produção musical hoje (fortemente presente nas mídias tradicionais, as massivas) está relacionada a resultados de pesquisas de mercado e de análise comparativa de dados de vendagem, tornando-se essa interferência um fator importante na constituição do gênero canção popular atualmente e, especificamente, a canção popular infantil.

\subsection{A CANÇÃO PELA PSICANÁLISE: O ACALANTO}

A boca é definida como instrumento de satisfação de necessidades fisiológicas como comer e beber, mas também como fonte de prazer. A psicanalista Santaella (2002) identifica que "[...] na fala está inscrita a possibilidade [de prazer] do canto. Encantamento do canto: fala transmutada em prazer" (SANTAELLA apud FALBO, 2010, p. 220).

A voz é ainda mais que uma fonte de prazer, é também uma "[...] ponte entre corpo e linguagem, identidade e alteridade" (FALBO, 2010, p. 221), é elemento determinante na construção no ser humano do seu "[...] estatuto de sujeito" (FALBO, 2010, p. 221).

A origem dessa relação com a voz é fundante e antiga, é um processo que se inicia nos primeiros anos da infância. A criança já ouve sons durante a gestação, notadamente a voz da mãe, e é por meio da audição, “[...] quando percebe as diferentes freqüências sonoras (alturas), que [se] constrói a noção de espaço no ser humano" (FALBO, 2010, p. 221). É também por meio da audição que o bebê é acalentado, geralmente, pela voz da mãe, e por uma performance que envolve mais do que apenas o canto, mas todo um engajamento afetivo, físico, corpóreo entre o bebê e a mãe que o suspende e embala.
A cantora e psicanalista MarieFrance Castarède (apud FALBO, 2010) associa o acalanto entoado pela mãe e seus efeitos sobre a criança ao "sentimento oceânico", apontado por Freud como o fundamento da religiosidade humana. $\mathrm{O}$ acalanto seria "[...] paradigmático como restituidor da sensação de plenitude do bebê no ambiente do útero materno, perdida logo após o nascimento" (FALBO, 2010, p. 221).

Talvez seja essa, psicanaliticamente, a fonte do encanto e do prazer que o canto provoca no ser humano, uma restituição da sensação de plenitude perdida, afinal o acalanto e sua performance acalenta a pulsação sinérgica entre ambos, orientada pelo percurso vibratório, ondulatório da canção da mãe para o bebê.

Essa sintonia remonta a uma situação anterior, um ordenamento de pulsões semelhante ao modelo sociocognitivo e cultural do acalanto, como assinala o crítico literário José Miguel Wisnik: "O feto cresce no útero ao som do coração da mãe, e as sensações rítmicas de tensão e repouso, de contração e distensão vêm a ser, antes de qualquer objeto, o traço de inscrição das percepções" (WISNIK, 1989, p. 26).

Até agora, no entanto, falou-se da relação psicanalítica entre o bebê e a recepção dos sons do mundo e, especificamente, da voz materna, mas logo o bebê desenvolve a sua própria voz e esse fato é também basilar no "[...] desenvolvimento da noção de $\mathrm{Eu}$, que vai possibilitar sua interação com o Outro" (FALBO, 2010, p. 221).

Essa nova etapa no desenvolvimento cognitivo e psicológico é um processo que se inicia com o grito do recém-nascido. Ele, mais do que um descontentamento, assinala "[...] a descoberta de um novo meio de expressão que passará a ser utilizado de maneira cada vez mais deliberada e articulada pelo indivíduo em linguagem" (FALBO, 2010, p. 221). Esse meio de expressão vai além do pragmatismo da comunicação para "[...] inscrever-se 
também como ferramenta de tradução do indizível: a voz" (FALBO, 2010, p. 221).

Antes de articular a sua própria voz, antes mesmo de compreender a estrutura linguística formal do que lhe diz a mãe, a voz do Outro, o bebê percebe no acalanto algo ordenado, pleno, mas intraduzível:

\begin{abstract}
Quando a criança ainda não aprendeu a falar, mas já percebeu que a linguagem significa, a voz da mãe, com suas melodias e seus toques, é pura música, ou aquilo que depois continuaremos para sempre a ouvir na música: uma linguagem onde se percebe o horizonte de um sentido que no entanto não se discrimina em signos isolados, mas que só se intui como uma globalidade em perpétuo recuo, não-verbal, intraduzível, mas, à sua maneira, transparente (WISNIK, 1989, p. 27).
\end{abstract}

Castarède (apud FALBO, 2010) vê a voz como "agente mediador" entre o corpo e a linguagem. $O$ grito do bebê é a protovocalidade humana, ainda muito individual, mas já uma ação enunciativa de qualquer maneira:

Se o grito é a primeira expressão afetiva, a voz vai lhe suceder, introduzindo fenômenos sonoros especificamente humanos, como as vibrações harmônicas. Ela é mediadora entre o corpo e a linguagem [...] A voz é mediação, não apenas para o sujeito em si mesmo, entre seu corpo e a língua, mas com a voz do outro. Ela se encarna em um 'discurso vivo', para retomar a expressão de André Green. A fala levada pela voz é diferente do pensamento, pois ela é resultado de uma descarga motora. Falar de viva voz ao outro é se descarregar (CASTARÈDE apud FALBO, 2010, p. 211).

A poética vocal da canção, midiatizada ou não, traz o fascínio psicanalítico oceânico, o prazer pelo canto e pela reconstrução deste durante a audição e a compreensão de aspectos de situações interativas e sua relação com as organizações sociais enquanto condições discursivas (FALBO, 2010).

\section{PARÂMETROS SEMIÓTICOS DA CANÇÃO POPULAR BRASILEIRA}

A eficácia interativa da canção, segundo Tatit (1986), se intensifica na articulação e compatibilidade entre os elementos do sistema de representação linguístico e sonoro - a eficácia a que se refere o autor é semiótica, e não mercadológica. Na canção, o destinadorlocutor (D. $\left.{ }^{\circ} \mathrm{R} \quad \mathrm{loc}\right)$ se relaciona interdependentemente com o destinatárioouvinte (D. ${ }^{a}$ RIO ouv) e dois "fazeres" são postos em jogo. O destinador-locutor " [...] faz com que o destinatário-ouvinte (D. ${ }^{a}$ RIO ouv) deseje ouvir uma determinada canção" (TATIT, 1986, p. 03). Levando em consideração que o compositor faz uma obra, um espaço de interação e expressão, e o seu público faz uma audição, uma leitura dela, os dois "fazeres" se completam e podem ser organizados em um enunciado sintáxico dos modalizadores intencionais:

D. ${ }^{\circ} \mathrm{R}$ loc/saber fazer/ $\square$ D. ${ }^{a}$ RIO ouv/querer fazer/

onde o primeiro fazer (o do locutor) corresponde a "compor" e o último fazer (o do ouvinte) corresponde a "ouvir", ou seja, o destinador tem a competência modal de provocar a volição do ouvinte em favor da canção.

Tatit (1986) estabelece dentro da música brasileira três parâmetros semióticos para análise do gênero canção, com maior atenção dada à melodia do canto popular. $\mathrm{O}$ autor aponta a entoação da fala como celeiro de frases e percursos melódicos para o canto na canção brasileira, percebe ainda que existem regularidades estruturais entre a entoação da fala e a voz do canto e ordena a canção brasileira em três critérios de descrições metalinguísticas multimodais mais frequentes, já estabilizadas e rotinizadas, com processos de persuasão particulares. Wisnik ainda se referenda nesses critérios para falar da canção popular brasileira:

Sobre isso [interesse cancional específico: os achados na relação 
música e letra], vou falar um pouquinho do que diz o Luiz Tatit, que diz o seguinte: a palavra, quando a gente fala, ela não tem regularidade rítmica, ela é irregular, o ritmo da fala é irregular. Quando a gente fala, também a gente melodiza pela entoação, mas a entoação também é irregular, ela não é estabilizada, não é definida. Enquanto que na música, o ritmo e a entoação, a melodia, ficam estabilizadas em notas, em pulsos, em tempo, em regularidades, em compassos, etecetera. Então a música tem uma periodicidade que a fala não tem. Na canção, essas duas instâncias, a música e a fala, começam a trocar as suas propriedades. Tem canções onde a palavra recebe uma injeção de regularidade musical [...] Ou seja, você sabe, são aquelas melodias que são feitas de pequenas células, módulos geralmente de intervalos curtos que tem uma certa geometria que vai criando um rendilhado e vai apontando para um lugar que você adivinha qual é, você sabe pra onde vai essa melodia quando ela começa esse desenho, e vai indo, vai apontado, você sabe onde vai dar. E são as melodias que tem mais um apelo somático, a gente começa a balançar junto com elas, a gente se entrega a elas, porque elas estão oferecendo o caminho e dizendo 'eu vou por aqui, vem junto!', e a gente vai com toda essa regularidade... Essas canções ele [Tatit] chama de tematizantes (WISNIK; PIEDADE; MEHMARI; FIAMMENGHI, 2015).

Cada parâmetro semiótico tem os seus processos particulares de persuasão. A tematização é um parâmetro que exerce a sua persuasão por meio da reiteração melódica, “[...] através dela, podemos reconhecer o que já ouvimos e prever o que ainda ouviremos" (TATIT, 1986, p. 47). A reiteração garante maior independência melódica, a linha melódica é tantas vezes repetida que se tornam evidentes o seu percurso, daí surgem os temas - todo esse processo se chama tematização. $\mathrm{O}$ parâmetro musical mais importante na tematização é a duração (pulso, ritmo), apesar da importância do perfil melódico (ascendente, descendente, pontilhado, ondulante etc.) manter o caráter tematizante da canção.

A melodia mais se afasta da entoação da fala, pois até a presença da voz entra nessa dimensão obsessiva de reiteração melódica. Há nesse parâmetro melódico da canção uma supervalorização do gênero musical, o texto linguístico fala sobre o gênero executado, ele o exalta, diretamente ou a um objeto-modal que o represente, pois, de acordo com Tatit, a exaltação é o correspondente textual da tematização.

A tematização é portadora de uma persuasão somática e possui como fator eufórico a sua empatia cognitiva com o gênero musical. A periodicidade funciona como um dispositivo de compatibilidade entre a melodia e o texto, do ponto de vista lógico (a periodicidade dos temas) e sensitivo (as vibrações): "[...] o centro da tensividade instala-se na ordenação regular da articulação, na periodicidade dos acentos e na configuração de saliências, muito bem identificadas com o tema" (TATIT, 1995, p. 10). Outros recursos do texto linguístico das canções tematizantes são as reiterações de rima internas e externas, aliterações e estímulos sensoriais de expressão.

\section{A ESCOLA E O DISCURSO ARTÍSTICO}

O estudioso da literatura infantojuvenil Francisco Aurélio Ribeiro (2010) defende posições sobre o papel da escola e do educador na formação de leitores (leitura aqui compreendida em sentido amplo, e não apenas no tocante ao texto escrito) que são relevantes ao debate sobre o lugar das produções artísticas infantojuvenis - seja a literatura (e a palavra escrita, como pontua Ribeiro), seja a canção popular, especificamente a infantil (e a palavra cantada, como é proposto por este artigo).

Ele também alerta sobre o pragmatismo a que o mercado e a escola condenam a arte da palavra destinada ao público infantil, e seus apontamentos podem 
ser atualizados no caso do cancioneiro popular infantojuvenil também.

Toda arte é simbólica. A literatura enquanto "arte da palavra", poderá perder seu valor de dialogar mais profunda e abrangente com maior número de receptores, não despertando a reflexão e a criação que se devem esperar de um texto artístico, se pretender privilegiar o caráter educativo ou informativo em detrimento do literário. [...] $\mathrm{O}$ educador deve descobrir, para poder transmitir, que a leitura é o estabelecimento de diálogos entre os homens, no tempo e no espaço [...] Ler é ver o mundo e, mais do que isso, uma forma de reescrevê-lo, segundo o mestre Paulo Freire (RIBEIRO, 2010, p. 34).

Esse tipo de discurso, o artístico, o literário, o poético, ainda segundo Azevedo (2004), é fundamental para a formação do sujeito do conhecimento. O conhecimento analítico, científico, heterogêneo e objetivo não deve ser a única preocupação da escola e do educador. É importante reafirmar o papel fundamental que o discurso poético tem na formação humanista do discente, no desenvolvimento de mecanismos empáticos de relação com a alteridade e na inserção cidadã dos sujeitos na vida social.

A literatura e outras fabulações (como a canção) demonstram-se peçaschave do processo de ensino e aprendizagem e na formação de leitores em todos os níveis do ensino, apesar de ocuparem espaços ainda periféricos nos planos de ensino e no currículo básico. Nesse contexto, o discurso artístico deve compor as formas de expressão dos alunos, pois

[...] o contato com textos subjetivos, movidos a visões pessoais e não consensuais, carregados de ficção e poesia, que se permitem utilizar a linguagem com liberdade, é outro ponto instigante da literatura, seja ela infantil ou outra. E já que vivemos em tempos tão pragmáticos e objetivos onde "tempo é dinheiro" e tudo precisa ter uma função lógica, sugiro que tal contato seja visto como uma espécie de "utilidade" da literatura. Se pensarmos na escola, mais ainda: afinal, a escola não se propõe a formar indivíduos que saibam se expressar? (AZEVEDO, 2005, p. 38).

O discurso artístico "[...] transforma o que é heterogêneo em homogêneo, sintetiza e é capaz de unir ou estabelecer a convivência entre elementos contraditórios" (AZEVEDO, 2005, p. 29). E qual é o lugar da canção infantil? Não terá esse nicho uma particularidade formal em relação ao nicho mais amplo da canção popular? Será que apenas as relações de produção e a criação de um nicho de consumidores de canção infantil sustentam esse campo de fabulação?

Ricardo Azevedo, pesquisador de literatura infantil, destaca os estudos sobre as cantigas trovadorescas do medievalista Paul Zumthor para tratar dos “[...] índices que caracterizariam os discursos orais, proferidos em perfomance", dos quais participa a canção popular, inclusive a infantil. Ele enumera três índices:

[...] 1) a adaptabilidade às circunstâncias. Para poder se comunicar, segundo Zumthor, o orador costumava utilizar vocabulário público e acessível e levar em conta o contexto em que o discurso estava ocorrendo; 2) a teatralidade. Um conjunto variado de recursos como o lugar-comum, o tom exagerado e hiperbólico; o uso de redundâncias; o tom de confidência; as brincadeiras com palavras (aliteração e trocadilhos), as rimas e refrões; recursos enfáticos como a reiteração, a enumeração; repetições de palavras; o uso da alegoria; metáforas; o estilo coloquial etc., mas note-se, não para fazer experiências formais com a linguagem e, sim, com o intuito de divertir, seduzir e prender a atenção do ouvinte; 3) a concisão (AZEVEDO, 2005, p. 40-41).

\section{ANÁLISE LÍTERO-MUSICAL}

\author{
5.1 ANÁLISE DE ACALANTOS DO \\ ÁLBUM “CANÇÕES DE NINAR” (1994), \\ DE PALAVRA CANTADA
}


As cantigas de ninar que compõem a primeira obra do projeto paulista que acabou por se especializar em produção de canções e espetáculos infantis são (quase) todas inéditas. $\mathrm{O}$ projeto Palavra Cantada é capitaneado por Paulo Tatit e Sandra Peres.

O álbum "Canções de Ninar" (PERES; TATIT, 1994) é formado por canções populares, algumas de autoria de Paulo Tatit e Sandra Peres, outras são assinadas pela dupla juntamente com parceiros como Edith Derdyk, Ná Ozzetti, Luiz e Zé Tatit, Akira Ueno, Neco Prates e Zé Miguel Wisnik, além de obras de autoria de outros compositores como Pedro Mourão, Rodolfo Stroeter, Edgar Poças e Hélio Ziskind ou até mesmo autores mais consagrados como Arnaldo Antunes, Caetano Veloso, Cid Campos e Augusto de Campos. Esse álbum foi vencedor do Prêmio Sharp no ano de seu lançamento na categoria de Melhor Disco Infantil daquele ano.

Os 22 acalantos enfeixados nesse álbum renovam o repertório de berço, sem fugir às características tradicionais desse subgênero textual, tão marcadas pelas suas manifestações folclóricas. A tematização no nível musical se realiza no nível verbal de modo a erigir um objeto que será tematizado, processo que Tatit chama de exaltação, por vezes iconizando elementos relacionados culturalmente ao gênero musical executado. No caso da canção de ninar, I) a situação enunciativa própria do acalanto é tematizada em diversas obras desse subgênero, sejam folclóricas ou populares; por vezes, no entanto, II) a própria criança a que se destina ninar se torna objeto da letra da canção; ou ainda é III) a noite e sua afabilidade que é tematizada no nível verbal.

Aliam-se ao processo de perseguição obsessiva de um percurso melódico na busca pela eficácia e pelo encanto das canções de ninar, efeitos de humor provocados pelo esmero formal e pelo trabalho com sons, letras, palavras, imagens, conceitos etc. A descarga de prazer do jogo de palavras, do jogo de ideias, da subversão das práticas cotidianas, das escatologias, da sonoridade de versos inusitados e não intelectivos etc.; tudo isso que está cheio de graça, de ludismo, de brincadeira, de jogo, de bobeira, é poesia e é humor também.

$\mathrm{O}$ humor é um recurso que atrai a atenção do destinatário-ouvinte. E, segundo Leo Cunha, pesquisador da literatura infantil, o humor em sentido amplo, não apenas o do chiste, é uma valiosa tecnologia educacional:

\begin{abstract}
Mas é importante ressaltar que mesmo um humor que não é claramente crítico, ou politizado, mesmo o humor que parece se limitar à brincadeira ou aos jogos de linguagem tem sua importância e seu valor, pois ele é capaz de despertar no leitor o gosto pelas palavras, o prazer de lidar de forma lúdica com os sons, os ritmos, e as formas das letras e palavras. Não será surpresa se, por meio de um poema como esse, a criança desconfiar (se não tiver certeza) de que qualquer texto pode esconder outros, pode trazer a ideia nova, o pensamento novo (CUNHA, 2005, p. 88).
\end{abstract}

A situação enunciativa é tantas vezes entoada e tematizada no álbum como comprovam os versos da cantiga que abre o disco, Vagarinho (Paulo Tatit / Edith Derdyk): "Vagarinho, vagarinho / Fecha o olho no seu ninho / E o sono vai chegar // E o sono no escurinho / Vagarinho, vagarinho / Põe o mundo pra sonhar...".

Aqui tanto a melodia e o canto, quanto a performance e o embalo, conjunto de fatores que integram o ato de ninar uma criança, são tematizados e a situação enunciativa atravessa o vagar melódico para manifestar-se linguisticamente. Essa linguagem informal, composta de reduções e diminutivos estreita os laços afetivos que se criam na situação enunciativa de acalentar um bebê.

As cordas mantêm uma regularidade na execução e acompanham a formulação de um tema melódico em uma performance que conta com a presença das vozes da dupla paulista, o que sugere a confluência da voz paterna e materna no ato de 
acalentar. Os ecos que se descolam das cordas da guitarra e se propagam graças à mesa de som "põem o mundo sonhar" com suas sugestões oníricas, ainda mais quando o teclado entra reproduzindo a percussão de um vibrafone e sugerindo por meio do seu som agudo e metálico imagens que recuperem elementos noturnos em favor da persuasão decantatória, como o brilho das estrelas.

Outro ponto que promove a eficácia desse acalanto é o humor presente no jogo de palavras "negro céu" / "noite véu" na mesma posição dentro da estrofe e da melodia. Como aponta Cunha:

Para a criança, a linguagem é um "espaço" privilegiado para a apreensão e compreensão do mundo. Por isso, brincar com palavras é uma atividade natural, que ela faz com prazer e por prazer. Não é à toa que trava-línguas, parlendas e outros jogos da tradição oral são tão populares entre os pequenos de todas as partes do mundo (CUNHA, 2005, p. 81-82).

Esse álbum é repleto dessas brincadeiras com as palavras. A canção de ninar Carneirinho 1, 2, 3 (Paulo Tatit) guarda uma brincadeira popular semelhante à canção folclórica Um elefante incomoda muita gente, brincadeira que consiste na repetição sequenciada de números em uma melodia tematizante com o acréscimo de mais um número ao final da sequência. No acalanto Lá vai alguém (Paulo Tatit / Zé Miguel Wisnik) ocorre uma repetição do termo "alguém" por diversas vezes, a ele se unem outros termos de mesma terminação (quem, ninguém, sem, porém, bem, além, tem, vem), provocando entre os efeitos de sentido o de estranhamento (Hein?) de quem não sabe quem lá vem.

Na canção de ninar Chuva (Sandra Peres / Paulo Tatit), esse jogo com a sonoridade chega ao extremo. Na primeira estrofe da canção ("A chuva cai faz ti lim / O sapo coacha cha / O sino bate dim dom / Eu canto la la la la"), a sua inteligibilidade quase se parte em favor da musicalidade das palavras e dos seus ecos, ou seja, "[...] o poeta investe na graça que surge da sonoridade melodiosa, ou inusitada, das palavras, muitas vezes até em detrimento do sentido, ou seja, daquilo que é inteligível" (CUNHA, 2005, p. 83).

Em Acalanto para você (Ná Ozzetti / Neco Prates / Edith Derdyk), a tematização da situação enunciativa do ato de acalentar já se impõe no primeiro verso da canção, "Eu canto pra você dormir", em que a voz lírica, metalinguisticamente, aborda o próprio fazer de seu exercício comunicativo-pragmático.

O eu-lírico vai além, estabelece os objetivos de seu ato de fala, o intuito de fazer dormir, de organizar o mundo infantil por meio da criação de uma regularidade sonora que lhe passe a segurança da previsibilidade musical e dinamogenênica (“A Terra gira por um fio").

A performance dedilhada do violão na introdução segue acompanhando a voz feminina que se estende até ser amparada pela delicadeza de um piano - dois instrumentos harmônicos, o primeiro um instrumento de cordas muito presente na música popular e o segundo, de cordas percutidas e muito comum na música erudita. O ordenamento do universo da criança está, naqueles sussurrados momentos, por um fio - por um fio do violão e do piano, por um fio de voz, por uma linha melódica, pelas malhas de um embalo.

Há momentos, como em Sono, preguiça (Akira Ueno / Luiz Tatit), que a situação enunciativa é descrita na fabulação de uma encorajadora conversa informal beira-berço entre quem nina e aquele que é embalado: "Sono / Preguiça / Não tenha medo não // Fique calmo / Tranquilo / Pegue na minha mão // Sono / Preguiça / Tudo isso é muito bom".

Sua performance possui os silêncios que intervalam a execução do violão ocupados pela duração constante dos registros graves de outro violão, sugerindo uma pulsação acelerada pelo medo a que o eu-lírico se refere na letra. Com isso, o tom de diálogo afetivo se reforça ("Pegue na 
minha mão"), além de plasmar na forma da execução a necessidade de quietude para se atingir o relaxamento do sono ("Fique calmo / Tranquilo").

Em Carneirinho 1,2,3, um velho recurso para se conseguir dormir por meio da contagem de carneirinhos é encenado nesse acalanto, tangenciando a situação enunciativa a que se dedica o eu-lírico.

Em outras canções, como Boa noite (Paulo Taitit e Zé Tatit) e Dorme (Arnaldo Antunes), expressões ligadas ao ato de ninar uma criança são repetidas obsessivamente durante toda a execução, com justaposição de timbres ou inserções de harmonizações de coral.

O humor, que se baseia na reinvenção do cotidiano, presente em Boa noite, em Sono, preguiça e em Sono de Gibi (Hélio Ziskind), se une à tematização na tentativa de intensificar a eficácia e o encanto comunicativo desses acalantos, pois segundo Cunha,

O poeta também pode perceber (ou deixar aflorar) o humor que existe nas situações mais banais, que a criança encontra em seu dia-a-dia. Atento, ele percebe, em meio ao trivial, situações de espanto, surpresa, invenção, elementos que são muito próprios ao universo infantil, já que a criança ainda está conhecendo e aprendendo as coisas do mundo (CUNHA, 2005, p. 86).

Na primeira canção de ninar referida no parágrafo anterior, Boa noite, antes de cada monóstico, encontram-se falas tipicamente dos adultos com as crianças, falas da autoridade, falas da ordem, mas muitas delas guardam elementos escatológicos que desmistificam o lirismo desse subgênero musical e subvertem os tabus do mundo dos mais velhos ("Garoto que dá uma de bacana / Faz xixi, escova os dentes / E já pra cama [...] Ih, e agora nenê tá com cocô / E a mamãe já foi pra casa do vovô").

No Sono de Gibi, o eu-lírico é uma criança que reparte uma descoberta: "A luz apaga / Parece que / A gente / Escuta mais".
Ela então descreve o momento de dormir apenas usando o sentido da audição e assim aquela situação, antes tão corriqueira, agora ganha as asas da imaginação na mente da criança que canta ("Parece um bicho... uma / Cobra... um sapo... sei lá, / Será que vai mexer?...") - e também excita a imaginação daquela que a ouve, sem dúvida.

A criança também passa por um processo de tematização no nível linguístico desse subgênero multimodal. No acalanto De ninar (Cid Campos / Augusto de Campos), a repetição paralelística da pergunta "E a criança o que faz?" ao final de cada estrofe tematiza o próprio destinatário. Ela coloca a criança no centro das analogias que desenvolve entre ela e outros seres vivos, animais (peixe, vagalume, pato, sapo e gato) e humanos em funções sociais dentro do núcleo familiar, papéis possíveis de participarem do convívio da criança (a mamãe, o papai, o vovô e a vovó).

Aqui o humor vem também se aliar à tematização. Nesse ponto, o humor emerge do jogo com as ideias e os conceitos. A imagem do peixe a nadar, vaga após vaga se aproximando do sono do bebê no leito, recria uma imagem oceânica, a do bebê que descansa dentro d'água, no ventre da mãe.

A mesma imagem parece se delinear nos três versos da canção de Caetano Veloso, Tudo, tudo, tudo (Tudo comer / Tudo dormir / Tudo no fundo do mar). A voz da performance, que, em meio a ecos, sons sintetizados (efeito sonoro extraído do disco Deserttracks de Michel Redolfi) e uma marcação constante da percussão, balbucia a melodia, logo torna-se dobrada (acompanhada por uma outra voz) e vai abandonando no fluxo do registro apenas "iscas" da letra. A repetição dos versos por quatro vezes se incumbe de imergir o interlocutor nesse sentimento oceânico, além de remeter também ao sono das espécies no caldo primordial:

O poeta (e por meio dele, o leitor) enxerga e fala das coisas (ou pessoas, ou situações) como se as estivesse vendo pela primeira vez. Deste 
exercício surgem metáforas surpreendentes, imagens inusitadas, e, claro, divertidas (CUNHA, p. 85-86).

Cunha se refere ainda ao humor presente nas obras artísticas infantis que "[...] parodiam ditados populares, provérbios, anúncios, ou outros textos. A graça surge da subversão das expectativas, da desconstrução dos sentidos já estabelecidos" (CUNHA, 2005, p. 85). Em "Canções de ninar", a paródia ficou por conta de Soneca (Rodolfo Stroeter / Edgar Barbosa Poças) e o seu texto-base foi o consagrado conto popular de tradição alemã que foi compilado pelos Irmãos Grimm, Branca de Neve e os sete anões, $e$, especificamente, a canção $\mathrm{Hi} H o$, da animação da Walt Disney de mesmo nome. Nessa canção de ninar, a tradição oral dos contos infantis europeus encontra a tradição oral das canções numeradas, já referidas acima, o que enche de ludismo a recepção desse acalanto.

Também no acalanto Pro nenê nanar (Paulo Tatit / Zé Tatit), o eu-lírico tematiza a criança no nível verbal. Fica claro o desespero da voz poética, ela sugere um pai de uma menina recalcitrante em dormir, "O que é que um pai pode fazer / No meio da noite / Pro nenê nanar?".

A criança ao ser descrita ("Agora está sequinha / Mamou toda a camomila") vai deixando claro todas as ações empreendidas pelo pai na expectativa de fazer sua pequena pegar no sono ("Só falta uma voltinha até a / Esquina"), nem mesmo a alternativa metalinguística fica de fora do evento de acalentar a filha ("Ouça essas canções / Da tua fita de ninar”).

A tematização, linguisticamente representada pela exaltação da figura da criança durante todo acalanto, também se desdobra na exaltação do gênero musical que embala a duração desse acalanto ("Venha cá no colo / Pequenina tão manhosa / Que eu te canto a velha bossa / Nova"), tornando, por meio de uma obsessão lítero-musical, a bossa nova tema multimodal desse acalanto.
A exaltação da "velha bossa nova" resvala numa leitura que permite se refletir sobre as dicotomias novo-velho, tradiçãoinovação, e sobre os conflitos entre a criança e o adulto - interpretação que fica cada vez mais clara na canção devido à performance, quando, ao final, é possível ouvir bocejos do pai, vencido pela pequena, que ainda por cima dança.

$\mathrm{Na}$ canção Meu anjo sim (Sandra Peres / Zé Tatit), encontra-se operada novamente a tematização da criança enquanto objeto da canção. Ela aparece no centro da exaltação do acalanto ("Dorme, meu anjo lindo / Meu menino serafim"). Os contornos delicados da performance desse acalanto executada pelo piano remonta às canções religiosas eruditas exatamente para plasmar na forma angelical a força expressiva do destinatário tematizado. A persuasão decantatória atrai o interlocutor quando usa esse recurso, cuja inserção no nível verbal o seduz afetivamente.

Outra tematização linguística comum aos acalantos é a exaltação da afabilidade da noite. Na canção de ninar Negro céu (Sandra Peres / Edith Derdyk), a noite é o tema da letra e dela se destacam suas características ligadas à leveza (véu), beleza (luz do luar) e inefabilidade (noite do além). A letra desbarata o medo da escuridão e derruba o sol em favor dos prazeres oníricos, a noite passa a ser um convite ao sono ("Vai / Céu azul / Pro fim do mundo // Vem / Noite do além").

A performance musical desse acalanto ressalta a inefabilidade da noite pelos efeitos de sentido provocados pelo uso de uma programação de sintetizadores que sugere o som de um xilofone durante toda a execução e pela voz feminina que se estende em entoação melódica, com o uso da região aguda de seu registro e a extensão das frases melódicas. O coro, semelhante ao canto tradicional da cultura japonesa, $\min ^{\prime} y \bar{o} \mathrm{com}$ seus kakegoe (gritos que interseccionam a melodia em formato coral), aponta "pro fim do mundo" para onde vai o "céu azul" e de onde vem a "noite do além". 
Outro acalanto que exalta a noite como objeto temático que contemporiza com a ideia de sono é Dorme em paz (Paulo Tatit/Luis Tatit). A noite é tema no primeiro verso das duas primeiras estrofes, entoada exatamente no mesmo percurso melódico, ansiada que é para o sono da criança - e da mãe e do pai que ninam.

O papel das produções artísticas na formação de leitores e cidadãos desde a mais tenra infância, aproveitando de suas inclinações psicanalíticas ao acalanto para promover o contato com práticas sociais de leitura, é importante ao processo de ensino e aprendizagem. $\mathrm{O}$ contato infantil com esse subgênero deve ser melhor explorado pela escola e pelos educadores, além de ser estimulado pelos familiares desde sempre.

\section{CONCLUSÃO}

Este artigo apresentou a importância das produções artísticas na formação de leitores, aproveitando de suas inclinações psicanalíticas ao acalanto para promover desde a mais tenra infância o contato com práticas sociais de leitura.

Por meio da análise da eficácia comunicativa e do encanto estético da canção de ninar, segundo os parâmetros semióticos, aliados a recursos linguísticos de exaltação e de humor em sentido amplo nos acalantos presentes no álbum "Canções de ninar", do projeto Palavra Cantada, foi possível observar como a canção (e, especificamente, a canção infantil em seu subgênero musical acalanto) possui a pluralidade de níveis de linguagem para estimular uma leitura híbrida e multimodal e a capacidade de afetar dinamogenicamente o interlocutor e, assim, instigá-lo ao exercício mais constante da leitura, afinal, apesar de aparentemente simples, a cultura e a arte popular conseguem dar conta das necessidades físicas e psicológicas das crianças.

As características do subgênero textual acalanto dentro do espectro de produções artísticas destinadas ao público infantil quanto à sua eficácia comunicativa, ao seu encanto estético e ao seu uso pedagógico na formação de leitores e no processo de ensino e aprendizagem desde os primeiros anos de alfabetização é o ponto central deste trabalho.

Do de vista dos parâmetros musicais semióticos, é possível perceber uma predominância nesse subgênero cancional da tematização, de reiteração de um tema e a consequente harmonização da psiquê infantil, aliados a recursos linguísticos de exaltação de um objeto lírico.

A figurativização aparece como outro importante parâmetro musical desse subgênero, com menos ocorrências na obra analisada, mas que, por meio de caminhos melódicos inconstantes, próximos da entoação da fala, é possível uma interação infantil com a paralinguagem de seus sistemas linguísticos e as práticas sociais de leitura e escrita.

Os recursos linguísticos descortinam a presença de uma voz com quem o destinatário-ouvinte possa manter sentimentos de empatia ou que leva a reflexões morais de situações cotidianas do universo da criança.

Chega-se, portanto, a conclusão de o gênero canção infantil em seu subgênero acalanto é uma peça valiosa para a formação pedagógica da criança, por meio da eficácia comunicacional e do encanto estético, nos níveis cognitivos, morais, éticos, dinamogênicos, estéticos e lúdicos, considerando-as enquanto leitoras em constante processo de alfabetização.

\section{REFERÊNCIAS}

ANDRADE, Mário de. Ensaio sobre a música brasileira. 3. ed. São Paulo: Martins, 1972.

AZEVEDO, Ricardo. Aspectos instigantes da literatura infantil e juvenil. In: OLIVEIRA, Ieda de (org.) O que é qualidade em literatura infantil e juvenil - Com a palavra o escritor, São Paulo, DCL, 2005, p. 25-46. 
BAKHTIN, M. Os gêneros do discurso. In: BAKHTIN, M. Estética da criação verbal. São. Paulo: Martins Fontes, 2003. p. 261306.

CALAZANS, J. H. C. A criação de um gênero textual a partir das relações onde, quem e o que: espaço, sujeito e ideologia. In: Intercom, Recife, 2011.

COSTA, Nelson Barros da. Canção popular e ensino da língua materna: o gênero canção nos Parâmetros Curriculares de Língua Portuguesa. In: Linguagem em (Dis)curso. Tubarão, 2003, p.9-36.

; GONZALEZ, B. N. A. C.. A produção do discurso literomusical brasileiro para crianças? Uma proposta de investigação discursiva. In: Abralin em Cena Amazonas, 2014, Manaus. Abralin em Cena Amazonas. Manaus - AM: UEA edições, 2014.

CUNHA, L. Poesia e humor para crianças. In: OLIVEIRA, Ieda de (Org.). O que é qualidade em literatura infantil e juvenil - Com a palavra, o escritor. São Paulo: DCI, 2005, p. 77-90.

FALBO, C. V. R. A palavra em movimento: algumas perspectivas teóricas para a análise de canções no âmbito da música popular. In: Per Musi, n. 22, Belo Horizonte: UFMG, 2010, p. 218-231.

MARCUSCHI. L. A. Produção Textual, Análise de Gêneros e Compreensão. São Paulo: Parábola Editorial, 2008.

PERES, Sandra e TATIT, Paulo. Canções de ninar. Coleção Palavra Cantada. São Paulo: Salamandra, 1994. Disponível em <https://www.youtube.com/watch? $\mathrm{v}=1 \mathrm{UrdP}$ DgWn08>. Acesso: 12 nov. 2018.

RIBEIRO, Francisco Aurélio. "A literatura infantojuvenil e sua utilização na escola. In: Ensaios de leitura e literatura infantojuvenil. Serra (ES): Editora Formar, 2010, p. 33-47.

RUFINO, Janaína de Assis. As notas da minha canção: considerações sobre o gênero canção. Recorte - Revista Eletrônica, v. 9, n. 2, 2012. Disponível em: $<$ http://revistas.unincor.br/index.php/rec orte/article/view/608/pdf $>$. Acesso em: 29 out. 2017.

TATIT, Luiz. A Canção, Eficácia e Encanto. São Paulo: Atual Editora, 1986.

TATIT, Luiz. Análise semiótica através das letras. 4. ed. São Paulo: Ateliê, 2001.

TATIT, Luiz. O cancionista: composição de canções no Brasil. São Paulo: EDUSP, 1995.

WISNIK, José Miguel. O som e o sentido. Uma outra história das músicas. São Paulo, Companhia das Letras, 1989.

; PIEDADE, Acácio; MEHMARI, André; FIAMMENGHI, Luiz Henrique. Mesa Redonda - A Canção Brasileira e a Música Instrumental [Registo vídeo]. In: Seminário de Improvisação Musical Brasileira. Florianópolis: Cinese Filmes, 2015. (1h52min). Disponível em: <https://www.youtube.com/watch?v=6BkN ZqcRPsw\&list=PLRJHFycO_yhhk7FfAjPs SBb65nEv9WGdb\&index $=4>$. Acesso em 21 dez. 2017. 